Evidence for spring mountain snowpack retreat

\title{
Evidence for spring mountain snowpack retreat from a Landsat-derived snow cover climate data record
}

\section{J. Crawford}

Department of Geography, University of Minnesota - Twin Cities 414 Social Sciences, 26719 Ave. S, Minneapolis, MN 55455, USA

Received: 8 April 2013 - Accepted: 10 May 2013 - Published: 31 May 2013

Correspondence to: C. J. Crawford (crawf188@umn.edu)

Published by Copernicus Publications on behalf of the European Geosciences Union. 


\section{Abstract}

A Landsat snow cover climate data record (CDR) of visible mountain snow-covered area (SCA) across interior northwestern USA during spring was compared with groundbased snow telemetry (SNOTEL) snow-water-equivalent (SWE) measurements and 5 mean surface temperature and total precipitation observations. Landsat spring SCA on 1 June was positively correlated with 15 May and 1 June SWE, negatively correlated with spring temperatures (April-June), and positively correlated with March precipitation. Using linear regression with predicted residual error sum-of-squares (PRESS) cross-validation, spring SCA was reconstructed (1901-2009) for the mountains of central Idaho and southwestern Montana using instrumental spring surface temperature records. The spring SCA reconstruction shows natural internal variability at interannual to decadal timescales including above average SCA in the 1900s, 1910s, 1940s1970s, and below average SCA in the 1920s, 1930s, and since the mid 1980s. The reconstruction also reveals a centennial trend towards decreasing spring SCA with estimated losses of $-36.2 \%$ since 1901 . Based on the inferred thermal relationship between temperature and snow, strong evidence emerges for mountain snowpack retreat triggered by spring warming, a signal that includes both feedback and response mechanisms. Expanding snow cover CDRs to include additional operational satellite retrievals will add temporal SCA estimates during other snow accumulation and melt intervals for improved satellite-instrumental climate model calibration. Merging Landsat snow cover CDRs with instrumental climate records is a formidable method to monitor climate-driven changes in western US snowpack extent over 20th and 21 st centuries.

\section{Introduction}

Documenting climate variability and change is dependent on the source of evi25 dence and its observational timescale. While instrumental, proxy, and written historical records provide most of the primary data for climate assessment and interpretation on
TCD

7, 2089-2117, 2013

Evidence for spring

mountain snowpack retreat

C. J. Crawford

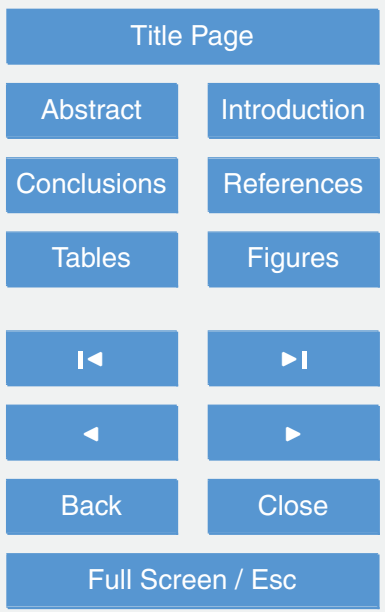

Printer-friendly Version

Interactive Discussion 
interannual to centennial timescales, Earth observing satellites and their data retrievals exist as a recent type of climate record since the mid 1960s (Matson and Wiesnet, 1981). In 1972, the Landsat mission launched with the Multi-Spectral Scanner (MSS), and since that time, additional platforms have followed including the Thematic Mapper 5 (TM), Enhanced Thematic Mapper Plus (ETM+), and now the Landsat Data Continuity Mission (LDCM). Thus, Landsat's observational timescale possesses key attributes for climate data record (CDR) development. The suite of Landsat platforms includes a continuous period of recurrent multispectral measurements, and with LDCM now retrieving imagery into the next decade; the Landsat record continues to grow on climatically relevant timescales (i.e., beyond the $30 \mathrm{yr}$ normal). More specifically, and arguably the most valuable attribute, data users have no cost access to the image archive at the USGS EROS Data Center. Coupled together, these characteristics place Landsat at the core of climate-cyrosphere CDR derivation and study.

Climatic warming poses serious threats to the seasonal cyrosphere (Barry, 2002).

15 As Earth's climate system continues to evolve and change, more satellite retrievals are acquired and archived, and future missions are planned, the significance of CDRs increase. Global and regional climate model projections show agreement on the pace of temperature rise in the coming decades (Meehl and Teng, 2012; Teng et al., 2006) even though precipitation models remain less certain regarding the liquid content of 20 snow (Duffy et al., 2006). Successive snow cover accumulation during the cool season followed by spring melt is vital for snow-dominated freshwater systems (Barnett et al., 2005), but is sensitive to short and long-term temperature change (Barry, 2006, 2002; Barry et al., 1995). Across the arid western United States, seasonal mountain snowpack accumulation and melt contributes approximately $50-70 \%$ to the total annual freshwater resource thru snow-fed streamflow (Cayan, 1996; Redmond and Koch, 1991). Several western US studies on snow course and snow telemetry (SNOTEL) snow-water-equivalent (SWE) measurements indicate that mountain snowpack is declining because of warming springtime temperatures (Cayan et al., 2001; Mote et al., 2005; Pierce et al., 2008; Westerling et al., 2006; Hamlet et al., 2005). Yet,

Evidence for spring mountain snowpack retreat

C. J. Crawford

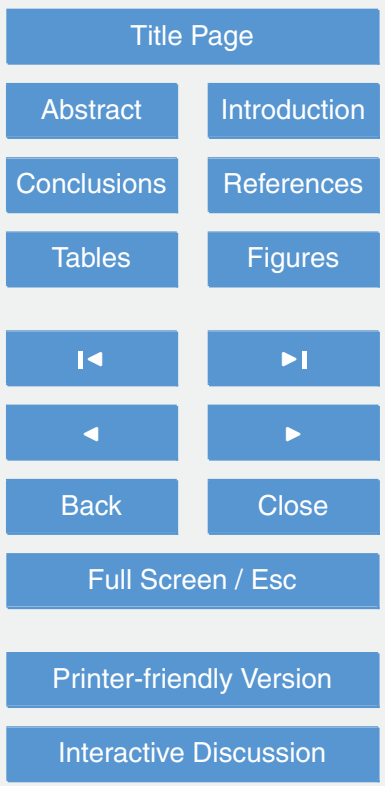


satellite-based study on mountain snowpack spatiotemporal variability is insufficient because CDRs do not yet exist for decadal timescales. To achieve this, CDRs derived from Landsat snow-covered area (SCA) estimates since the early 1970s fill this data need, especially for freshwater-sensitive regions of the western US. In response, 5 this paper compares a Landsat derived snow cover CDR (Crawford et al., 2013) with ground-based SNOTEL SWE, and surface temperature and precipitation observations. Landsat SCA is then reconstructed using instrumental climate records to examine longer-term trends in spring snowpack extent.

Merging satellite observations with ground-based instrumental data has been pro10 posed as a means to advance study on seasonal snow properties including extent, duration, depth, and water equivalent at finer spatial scales in mountainous terrain (Bales et al., 2006; Barry et al., 1995; Frei et al., 1999; Robinson, 1991). Snow accumulation, distribution, and melt heterogeneity is controlled by physiography, radiation, and energy exchanges, which in total, contributes significantly to snow cover and SWE variation across watershed-basin scales (Elder et al., 1991; Anderton et al., 2004; Cline et al., 1998). Comparisons between point-based SNOTEL SWE measurements and a continuous mean SWE grid has shown that SNOTEL SWE may not be representative across multiple spatial scales that in part, reflect sampling density and instrument location in areas with disproportionate accumulation and ablation rates (Molotch and Bales, 2005). Furthermore, a high proportion of SNOTEL measurements across the western US do not start until the late 1970s (Serreze et al., 1999), and are located in mid elevation zones with little sampling stratification across low and high elevation regions (Bales et al., 2006). This leaves SWE inadequately monitored in many high alpine basins (Nolin, 2012). Even so, satellite snow cover retrievals provide continuous spatial observations that can be exploited in the form of CDRs to monitor SCA over mountainous terrain. Adopting this Landsat snow cover CDR approach is especially powerful for identifying watersheds or basins where significant climate-driven changes in mountain snowpack are occurring. Merging satellite CDRs with SNOTEL SWE and instrumental climate records is not a replacement for current modeling efforts, only
TCD

7, 2089-2117, 2013

Evidence for spring mountain snowpack retreat

C. J. Crawford

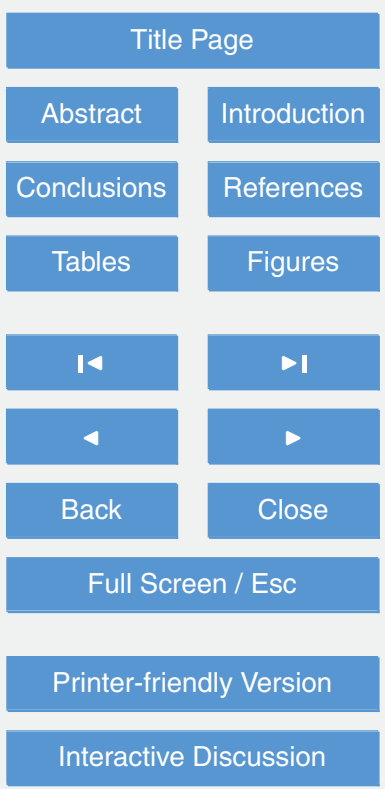


an additional method to track snow cover (snowpack) accumulation and melt trends on longer timescales. This method is particularly important for understanding alpine snowpack change and streamflow timing (Lundquist and Dettinger, 2005; Stewart et al., 2005; McCabe and Clark, 2005; Dettinger and Cayan, 1995), as well as identifying low 5 elevation zones where temperature-driven phase changes in precipitation are already underway (Knowles et al., 2006; Hall et al., 2012; Nolin and Daly, 2006).

Landsat snow cover CDRs have three spatiotemporal dimensions to examine mountain snowpack variability and change that include SCA extent (spatial domain), SCA elevational zonation (vertical domain), and SCA time-series variance (time domain). 10 SCA variability within each of these domains can be directly compared with SNOTEL SWE and surface temperature and precipitation using time-series analysis techniques. This paper uses a Landsat snow cover CDR that has been developed for spring peak snowmelt timing for an interior northwestern USA sub-region, namely the mountains of central Idaho and southwestern Montana (Crawford et al., 2013). The objectives are to (1) statistically compare Landsat SCA with SNOTEL SWE; (2) statistically compare Landsat SCA with surface temperature and precipitation observations; and (3) reconstruct Landsat SCA during 20th and early 21 st centuries to document long-term mountain SCA trends during spring melt.

\section{Methods}

\subsection{Landsat CDR description and instrumental climate data}

Landsat snow cover CDR coverage is centered over the mountains of central Idaho and southwestern Montana in the interior northwestern USA (Fig. 1). This CDR has been derived from the Landsat image archive including MSS, TM, and ETM+ imagery, and includes 1 June SCA (hereinafter spring SCA) as the spring snowmelt target (Crawford et al., 2013). The spring SCA CDR spans 1975-2011 with missing SCA estimates in 1973, 1974, 1978-1982, 1987, and 1988 because of missing image coverage or
TCD

7, 2089-2117, 2013

Evidence for spring mountain snowpack retreat

C. J. Crawford

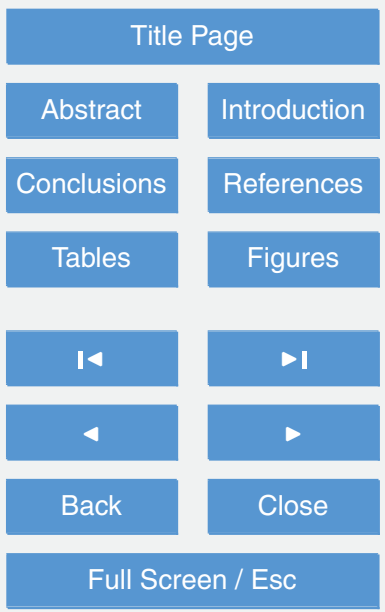

Printer-friendly Version

Interactive Discussion 
cloud cover contamination. Specific methods for Landsat data processing and CDR development are outlined in Crawford et al. (2013). SNOTEL SWE measurements for six stations falling within the study region (Fig. 1) were collected from the Natural Resource Conservation Service (NRCS) National Water and Climate Center at 5 http://www.wcc.nrcs.usda.gov/snow/. SNOTEL station metadata is summarized in Table 1. The high-resolution $\left(0.5^{\circ} \times 0.5^{\circ}\right)$ Climate Research Unit (CRU), University of East Anglia TS3.1 surface temperature and precipitation grid (Mitchell and Jones, 2005) was accessed through http://iridl.Ideo.columbia.edu/, and grid points for the study region were extracted (Fig. 1).

\subsection{Study region description}

The central Idaho and southwestern Montana mountains are part of the northern Rocky Mountain region, and situated in a mid-latitude continental position with steep vertical relief and fine scale topographic variability. The regional climate is semi-arid with a peak precipitation maximum during spring-early summer (Shinker, 2010; Mitchell, 15 1976). For this continental region, maximum snowpack accumulation occurs between early-mid April with peak snowmelt during early June (Cayan, 1996). Snow coverage during spring is largely confined to the mid and high elevations. Low elevation zones have already melted out during early spring.

\subsection{Landsat SCA - SNOTEL SWE comparison}

20 Bi-monthly SNOTEL SWE for 1 April, 15 April, 1 May, 15 May, and 1 June for each station were converted into $z$-scores using the station mean and standard deviation for the period of record. Estimated SWE prior to the start of snow telemetry on the 1st and 15th day of each month were excluded from the analysis. A six-station regional SWE $z$-score time-series was constructed using the six-station mean and standard devia25 tion. The regional SWE time-series was adjusted for the number of stations because of differing start dates. Spring SCA (i.e., a normalized percentage, see Crawford et al.,
TCD

$7,2089-2117,2013$

Evidence for spring mountain snowpack retreat

C. J. Crawford

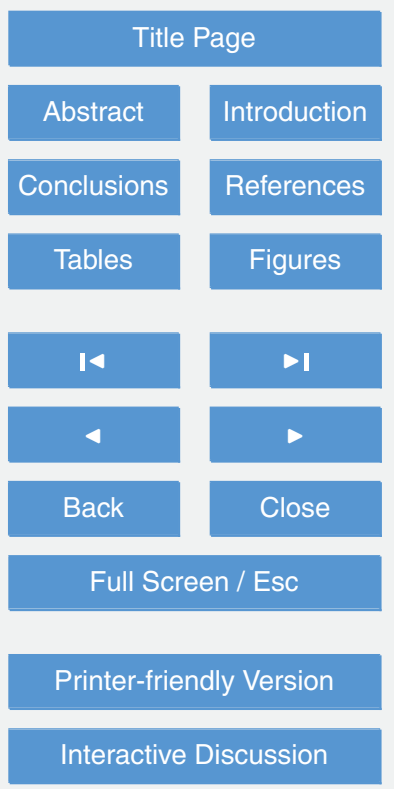


2013) estimates for 1975-2009 were compared with individual station SWE and regional SWE using scatterplots, linear fits, and correlation analysis. The selected time period for comparison was based on time-series overlap and data availability.

\subsection{Landsat SCA Correction}

5 During the spring snowmelt season, transient snowfall events in mountainous terrain are difficult to distinguish from resident snow cover when satellite image acquisitions are not daily ( $\mathrm{Li}$ et al., 2008). Since Landsat's image acquisition frequency is 16-18 days, transient snowfall can inflate SCA on the day of Landsat overpass and must be corrected. To correct for transient snowfall, Landsat SCA estimates are converted into $10 \quad Z$-scores using the SCA mean and standard deviation for the period of record. Positive SCA estimates falling beyond 1.96 (> 95\% confidence interval, one-tailed test) standard deviations are flagged as possible anomalies and are subject to further evaluation. Scatterplots between SCA $z$-scores and regional SNOTEL SWE $z$-scores are used to identify outliers and the year of occurrence. Once the year has been identified, daily SNOTEL SWE measurements for stations falling within the CDR geographic domain are inspected for days preceding Landsat's overpass. Transient snowfall is confirmed within 1-3 days if SWE temporarily increases along a seasonally decreasing SWE curve (i.e., snowmelt curve). It is preferable to observe SWE increases at multiple SNOTEL stations within the CDR domain. A Landsat SCA correction is then applied by removing the SCA outliers, deriving a linear equation that relates SCA to regional SWE, and then uses regional SWE to predict resident SCA for years with transient snowfall. This Landsat SCA correction approach mimics the widely used methods in statistical climatology to estimate missing values for in situ climate data (Eischeid et al., 1995; Peterson et al., 1998).
TCD

7, 2089-2117, 2013

Evidence for spring mountain snowpack retreat

C. J. Crawford

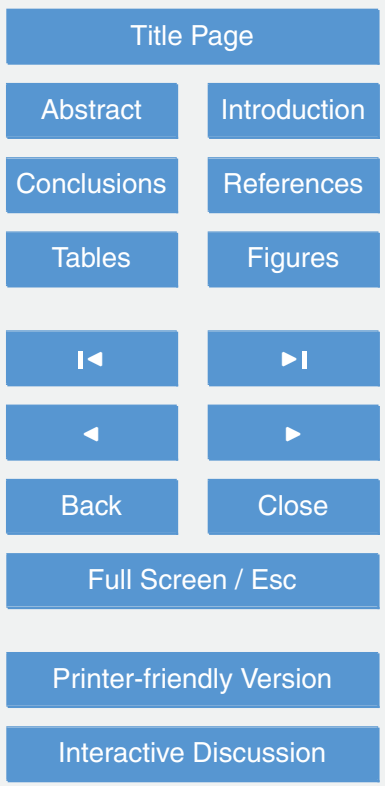




\subsection{Landsat SCA - surface temperature and precipitation comparison}

Spring SCA estimates for 1975-2009 were compared with mean monthly surface temperature and total monthly precipitation for months January to June using scatterplots, linear fits, and correlation analysis. SCA estimates were also compared with season5 alized mean temperature (i.e., mean) and total accumulated precipitation (i.e., sum). Regional mean temperature and total precipitation time-series were constructed from CRU TS3.1 grid points covering the CDR region that included $0.5^{\circ}$ grid points surrounding the CDR boundary to reduced edge effects (Fig. 1). The regional mean temperature time-series was calculated using the average of all grid points (Jones and Hulme, 1996). The regional precipitation time-series was calculated using unrotated principal component analysis (PCA) to identify the dominant spatial mode of precipitation variability at monthly and seasonal timescales (Comrie and Glenn, 1998). The statistical significance of each correlation coefficient was tested at $p<0.05$ (two-tailed).

\subsection{Landsat SCA reconstruction and trend analysis}

15 Spring SCA estimates were reconstructed for the CDR region during 1901-2009 using regional CRU TS3.1 instrumental climate records. A stepwise "leave-one-out" linear regression model with predicted residual error sum-of-squares (PRESS) cross-validation was employed to develop the spring SCA reconstruction (Michaelsen, 1987; Wilks, 1995). The pool of potential predictor variables included statistically significant monthly 20 and seasonal mean temperature and total precipitation correlations. Because the Landsat spring SCA CDR was continuous only for 1989-2009, this $21 \mathrm{yr}$ period was used for model calibration. "Leave-one-out" validation statistics were generated for each step to assess model skill and accuracy during the calibration period. A Durbin-Watson test assessed model residuals for autocorrelation, and regression residuals were evaluated fort statistic (Ostrom, 1990). The reduction of error $(\mathrm{RE})$ and root-mean-squared error $\left(\mathrm{RSME}_{\mathrm{v}}\right)$ cross-validation statistics determined model construction, fit, and performance (Michaelsen, 1987). Error bars
Evidence for spring mountain snowpack retreat

C. J. Crawford

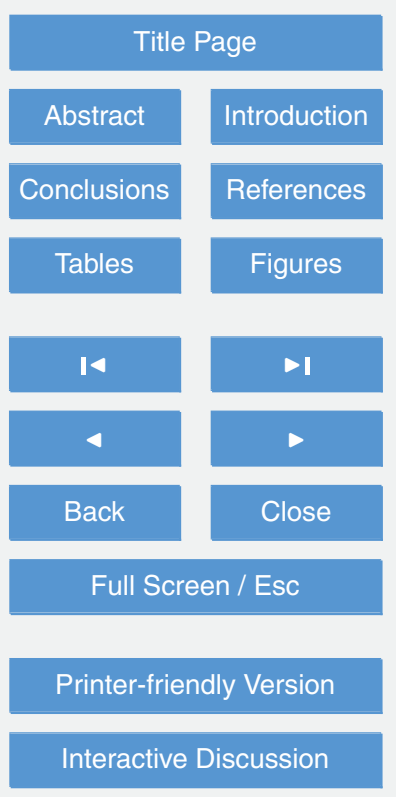

Interactive Discussion 
were generated for $p=0.10$ and $p=0.90$ (80\% confidence level) for the final spring SCA reconstruction to insure the plausibility of SCA estimates given model uncertainty.

Since the Landsat spring SCA CDR was discontinuous with missing SCA estimates in 1973, 1974, 1978-1982, 1987, and 1988, reconstruction model verification was car5 ried out using independent Landsat spring SCA estimates in 1975, 1976, 1977, and 1983-1986. Reconstructed and observed spring SCA estimates having the same $z-$ score (i.e., reconstructed and observed SCA estimates where scaled to the calibration spring SCA mean and standard deviation) positive (negative) sign were considered "successful predictions" because of a limited number of verification samples $(n=7)$. 10 An exact binomial probability test was used to distinguish "successful predictions" from random chance $(p=0.5)$. Finally, reconstructed spring SCA estimates during 19012009 were evaluated for trend using a modified Mann-Kendall test (Yue and Wang, 2004). This non-parametric technique removes the serial correlation from the timeseries, and then uses a Mann-Kendall test to determine whether the trend is statisti15 cally significant given an effective sample size. A percent SCA change estimate was also derived for the 1901-2009 reconstruction.

\section{Results}

\subsection{Landsat SCA - SNOTEL SWE comparison}

Landsat spring SCA is positively correlated with SNOTEL SWE at individual stations within the CDR region (Table 1). The strongest spring SCA-SWE association corresponds to previous 15 May bi-monthly SWE. SCA correlations are much weaker for preceding bi-monthly SWE intervals and show a varying individual station response. The elevational difference between SNOTEL SWE station measurements, and local scale snowmelt timing, prevents SCA-SWE comparisons later in the snowmelt season. Landsat spring SCA is positively correlated with regional SWE during previous 15 May and current 1 June bi-monthly intervals, respectively (Fig. 2). Transient snowfall events
TCD

$7,2089-2117,2013$

Evidence for spring mountain snowpack retreat

C. J. Crawford

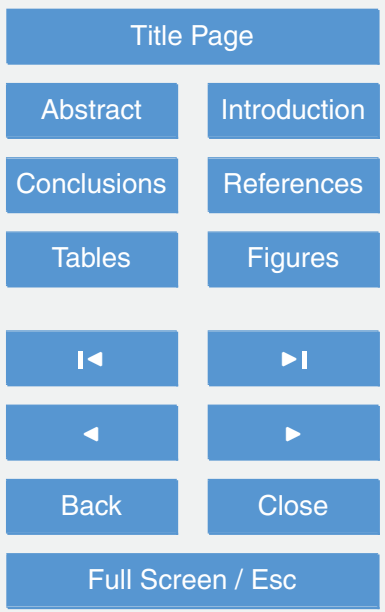

Printer-friendly Version

Interactive Discussion 
during the snowmelt season significantly affect the SCA-SWE linear relationship in time (Fig. 2).

\subsection{Landsat SCA correction}

Transient snowfall events inflated Landsat spring SCA estimates, and were identified as 5 statistical outliers in years 1990 and 2002 (Fig. 2). Daily SNOTEL SWE measurements preceding Landsat's overpass in 1990 and 2002 showed temporary SWE increases along a continuously decreasing snowmelt curve (Fig. 3). For 1990, three SNOTEL stations with available SWE measurements recorded a transient snowfall event between 31 May and 1 June. For 2002, five SNOTEL stations recorded a transient snowfall event between 22 May and 24 May. Spring SCA estimates for 1990 and 2002 were removed from the CDR, and resident spring SCA was estimated using 15 May regional SWE for 1990 and 2002.

\subsection{Landsat SCA - surface temperature and precipitation comparison}

Landsat spring SCA is negatively correlated with regional April, May, and June mean

temperature (Fig. 4). Spring SCA had the strongest inverse response to regional spring mean temperature (April-June) (Fig. 4). Spring SCA was also positively correlated with regional March precipitation PC-1 ( $r=0.38, p<0.05$, not shown).

\subsection{Landsat SCA reconstruction and trend analysis}

Landsat spring SCA was reconstructed (1901-2009) for the CDR region using May20 June mean temperature (Fig. $5 a$ and b). May-June mean temperature was the only statistically significant stepwise "leave-one-out" regression predictor for the 1989-2009 calibration period. The model explained $58 \%\left(\operatorname{adj} . r^{2}\right)$ of the spring SCA variance with strong PRESS validation statistics (Table 2). Durbin-Watson and Portmanteau $Q$ test statistics indicated no significant autocorrelation, no trend, and pure randomness in the residuals (Table 2). It is important to note that even though spring mean temperature

Evidence for spring mountain snowpack retreat

C. J. Crawford

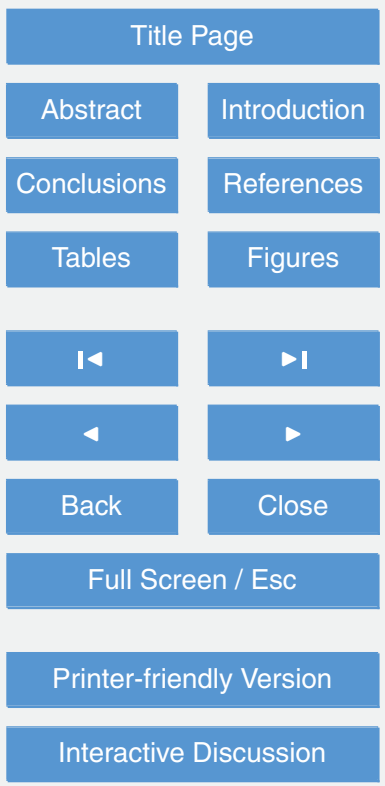


(April-June) had the highest correlation with spring SCA during 1975-2009, May-June mean temperature produced the most statistically significant spring SCA model for the 1989-2009 calibration.

Reconstructed spring SCA estimates for verification years 1975, 1976, 1977, and

5 1983-1986 indicated that independently observed spring SCA estimates shared the same sign in five out of seven cases (Fig. 6). The probability of same sign occurrence if reconstructed and observed spring SCA estimates are scaled to the calibration mean and variance is $p=0.164$. The May-June mean temperature model of spring SCA generally underestimated actual SCA outside the calibration period (1989-2009) as observed independently by Landsat. Reconstructed spring SCA during 1901-2009 showed a statistically significant decreasing trend per the Mann-Kendall (MK) test (MK $=-0.13, p=0.0486)$. Based upon the May-June mean temperature model, there has been a $-36.2(\%)$ decrease in spring SCA since 1901 across the central Idaho and southwestern Montana mountains (Fig. 5c and Fig. 1).

\section{Discussion}

The Landsat image archive is an unparalleled satellite database of multispectral observations that can be used to develop CDRs of visible SCA for western US mountain snowpack extent monitoring at fine spatial scales (Crawford et al., 2013). This study merges a Landsat snow cover CDR of spring SCA with ground-based instrumental climate records to extend the available time period for climate-snowpack analysis, specifically resolving natural internal variability and temperature-driven SCA decreases associated with modern climate change. This method is similar to the approach taken by Robinson (1991) and Frei et al. (1999) to merge NOAA Advanced Very High Resolution Radiometer (AVHRR) snow charts with ground-based snow depth measurements. Barry et al. (1995) suggest that better-quality information on spatial and temporal snow cover extent, duration, depth, and water equivalent variability including association to temperature and precipitation improves the ability to assess changing climatic

Evidence for spring mountain snowpack retreat

C. J. Crawford

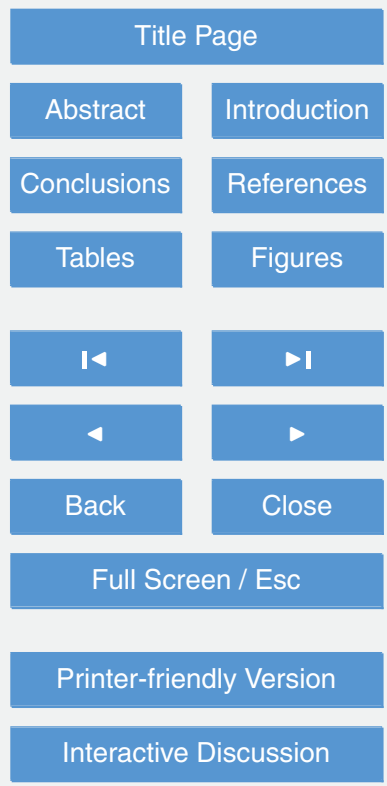

Interactive Discussion

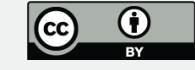


conditions and long-term trends. They point out that no one satellite platform or method is sufficient to provide all the required information, but that integration between multiple satellites and instrumental observations is more comprehensive.

Landsat spring SCA estimates share significant covariance with regionalized SNO5 TEL SWE observations during the previous and current bi-monthly measurement intervals (i.e., 1st and 15th of each month). When Landsat spring SCA estimates are compared with individual SNOTEL SWE stations, the SCA-SWE relationship appears spatially dependent over time. This suggests that not all SNOTEL SWE stations adequately represent spring SCA variance within a spatially explicit domain. This finding 10 is consistent with Molotch and Bales (2005) and Bales et al. (2006) suggestions that SNOTEL SWE stations do not capture snow ablation heterogeneity well in complex mountainous terrain. This time domain spatial dependence between SCA and SWE may be partly to blame for why snow distribution models perform poorly in certain locations (Erxleben et al., 2002). Equally important to consider, regionalized and individual SNOTEL station SWE during the often-cited 1 April peak mountain snowpack accumulation period for the western US (Cayan, 1996) showed weak association to spring SCA later (i.e., 1 June) in the melt season. Anderton et al. (2004) conclude from snow surveys that maximum snow depth and date of snow disappearance could largely explain the spatial patterns in snow ablation, and suggest that melt rates during the snowmelt season are unimportant. In contrast, results obtained here suggests that over time, peak SWE accumulation at the beginning of spring would have little skill when predicting SCA later in the snowmelt season. Moreover, to account for the potential time-dependent relationship between SCA and SWE across mountainous terrain, temporally discrete examination intervals are required to normalize seasonal trend in spatial snow accumulation and melt processes and patterns. This is of particular importance when the objective is to isolate climate driven change in snow cover (snowpack) because multiple accumulation and melt events can occur throughout the snow season (Liston, 1999) as shown in 1990 and 2002.
TCD

7, 2089-2117, 2013

Evidence for spring mountain snowpack retreat

C. J. Crawford

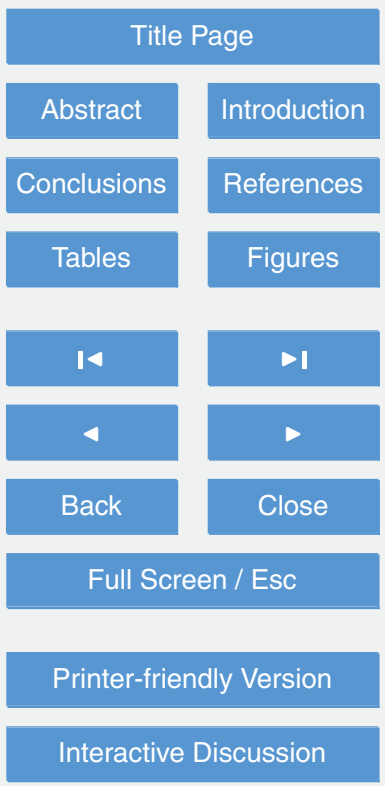


The inverse association between snow and temperature is well established (Barry, 2002; Barry et al., 1995; Groisman et al., 1994) including its relationship to orography and sea-level pressure (Sobolowski et al., 2007), sea surface temperatures (McCabe and Dettinger, 2002), and atmospheric circulation patterns (Clark et al., 2001; 5 Hurrell, 1996; McCabe and Legates, 1995). This study confirms that below (above) average mountain SCA across the interior northwestern USA has significant linear dependence on warm (cool) spring temperatures. Spring SCA did show a late winter response to March precipitation, but spring temperature was still the overriding signal. Using NOAA AVHRR snow charts, Leathers and Robinson (1993) showed that 10 positive (negative) snow cover extent anomalies over North America are strongly associated with below (above) normal wintertime surface temperatures. Warming winter temperatures in California since the 1940s have been linked to shifting winter atmospheric circulation patterns over the North Pacific Ocean, and have been suggested as the main driver behind earlier snowmelt runoff in mid elevation basins (Dettinger and Cayan, 1995). Groisman et al. (1994) find a strong feedback between spring snow cover extent and northern extratropical land radiative balance. They suggest that 20th century spring warming has been amplified by changes in snow cover extent. More specifically, Stewart et al. (2005) find that earlier streamflow timing across western North America is a response to spring warming, a signal that would be promoted by earlier snowmelt and less SCA during spring. This spring SCA reconstruction in interior northwestern USA supports both of these studies. The weaker SCA response to March precipitation indicates that late winter precipitation contributes to spring SCA variability, but that its interannual predictability is secondary to spring temperature. The nature of this spring SCA temperature response in the continental sub-region of central Idaho and southwestern Montana corroborates high SWE-precipitation ratios (i.e., increased temperature influence) found for Idaho and Montana (Serreze et al., 1999). This continental sub-region and snow cover climatic response falls within alpine and mountain snow classification categories outlined by Sturm et al. (1995).
TCD

7, 2089-2117, 2013

Evidence for spring mountain snowpack retreat

C. J. Crawford

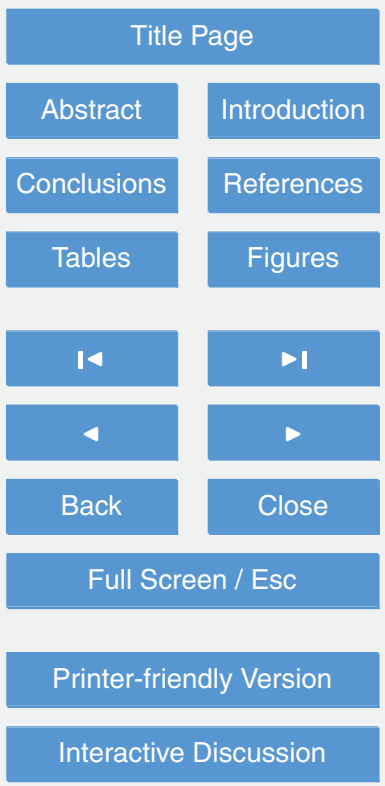


A trend towards decreasing spring SCA during the 20th and early 21st centuries is apparent across the central Idaho and southwestern Montana mountains. Using a spring surface temperature model that is well validated and showed encouraging verification with independent observations, the trend analysis indicates that there has 5 been a $-36.2 \%$ decrease in spring SCA since 1901. On the other hand, natural internal variability in spring SCA is evident on interannual to decadal timescales including above average periods during the decades of 1900s, 1910s, and 1940s-1970s. Periods of below average SCA occur during the 1920s, 1930s, and continue to remain largely below average since the mid-1980s. Hamlet et al. (2005) point out that decadal climate - variability associated with Pacific Ocean climate dynamics is not enough to explain warming winter temperatures and decreasing 1 April SWE trends across the western US. Pierce et al. (2008) use an 1 April SWE/precipitation ratio along with simulated climate models to reproduce SWE/precipitation reductions in western US snowpack. Like Hamlet et al. (2005), they find that natural internal climate variability alone cannot explain SWE/precipitation trends. Of more importance, a longer-term centennial trend towards decreasing spring SCA has been identified and is superimposed on natural internal variability; an obvious sign of spring warming. Although Groisman and Easterling (1994) and Kunkel et al. (2007) find that instrumental snow observations are sensitive to measurement inhomogeneities and should be considered carefully when evaluating climatic trends, this spring SCA reconstruction was produced using Landsat and surface temperature records. This temperature-driven trend in spring SCA across central Idaho and southwestern Montana is consistent with declining mountain snowpack SWE documented for the western US (Hamlet et al., 2005; Mote et al., 2005; Pederson et al., 2011; Pierce et al., 2008), decreasing Northern Hemisphere spring snow cover extent (Brown and Robinson, 2011; Derksen and Brown, 2012), earlier trends towards North American spring snow ablation (Dyer and Mote, 2007), earlier disappearance of Arctic spring snow (Foster, 1989), mountain glacier recession (Barry, 2006), and summer minimum Arctic sea ice extent (Stroeve et al., 2007).
TCD

7, 2089-2117, 2013

Evidence for spring mountain snowpack retreat

C. J. Crawford

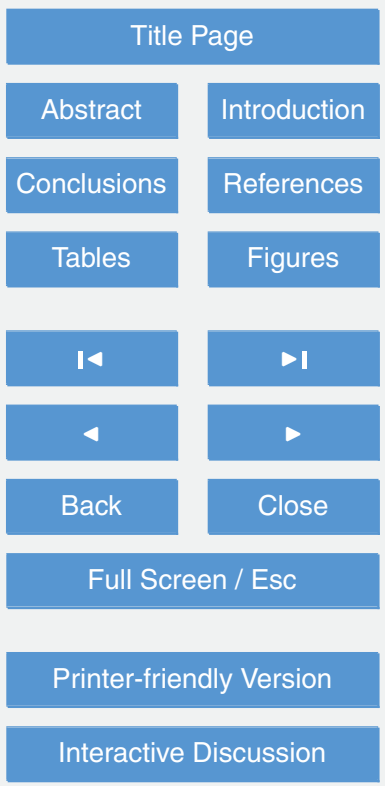




\section{Conclusion}

This Landsat snow cover CDR approach to monitoring SCA in mountainous terrain is sensitive to Landsat's image acquisition frequency, missing historical imagery, and transient snowfall at high elevations during the melt season. Such temporal gaps in SCA 5 estimation currently prevent longer more continuous calibrations with instrumental climate records, which limits model development and increases uncertainty and error. Even though the spring SCA reconstruction presented is based on a short calibration period, acceptable PRESS cross-validation statistics were obtained with a spring mean surface temperature model. Looking forward despite the documented limitations, SNOTEL SWE network across the western US offers discrete measurement resolution and adequate spatial coverage to anchor bi-monthly Landsat snow cover CDRs including corrections for transient snowfall events that inflate Landsat SCA estimates. Expanding snow cover CDRs to include the Landsat Data Continuity Mission (LDCM), Moderate Resolution Imaging Spectroradiometer (MODIS), and NPP Visible Infrared Imaging Radiometer Suite (VIIRS) retrievals from 2000 on will add to temporal SCA estimation, especially during other accumulation and melt intervals. Satellite-instrumental climate model calibration will certainly improve with additional temporal data acquisitions moving forward. The time-series analysis techniques deployed to reconstruct spring SCA from Landsat is straightforward in concept, design, execution, and provides a formidable statistical method to quantify temperature-driven decreases in SCA across the western US. Climatic warming induced trends towards decreasing Arctic sea ice and Northern Hemisphere spring snow cover, along with global mountain glacier recession, is also evident in spring mountain SCA. Sustained losses in seasonal SCA are clear, and can be expected to accelerate over the next several decades unless spring

Acknowledgements. A NASA Earth and Space Science Fellowship grant number NNX10A073H, Association of American Geographers Mountain Geography Specialty Group Research Grant, Association of American Geographers Dissertation Research Grant, and Department of Geography and College of Liberal Arts, University of Minnesota Dissertation Re- 
search Grants funded this study. I would like to thank Dorothy Hall, George Riggs, James Foster, Kurt Kipfmueller, Steve Manson, and Marvin Bauer for constructive feedback during the development of this research.

\section{References}

5 Anderton, S. P., White, S. M., and Alvera, B.: Evaluation of spatial variability in snow water equivalent for a high mountain catchment, Hydrol. Process., 18, 435-453, doi:10.1002/hyp.1319, 2004.

Bales, R. C., Molotch, N. P., Painter, T. H., Dettinger, M. D., Rice, R., and Dozier, J.: Mountain hydrology of the western United States, Water Resour. Res., 42, W08432,

Barnett, T. P., Adam, J. C., and Lettenmaier, D. P.: Potential impacts of a warming climate on water availability in snow-dominated regions, Nature, 438, 303-309, 7066, doi:10.1038/nature04141, 2005.

Barry, R. G.: The role of snow and ice in the global climate system: a review, Polar Geography., $15 \quad 26,235-246,2002$.

Barry, R. G.: The status of research on glaciers and global glacier recession: a review, Prog. Phys. Geogr., 30, 285-306, doi:10.1191/0309133306pp478ra, 2006.

Barry, R. G., Fallot, J. M., and Armstrong, R. L.: Twentieth-century variability in snow-cover conditions and approaches to detecting and monitoring changes: status and prospects, Prog. Phys. Geogr., 19, 520-532, doi:10.1177/030913339501900405, 1995.

Brown, R. D. and Robinson, D. A.: Northern Hemisphere spring snow cover variability and change over 1922-2010 including an assessment of uncertainty, The Cryosphere, 5, 219229, doi:10.5194/tc-5-219-2011, 2011.

Cayan, D. R.: Interannual climate variability and snowpack in the western United States, J. 25 Clim., 9, 928-948, 1996.

Cayan, D. R., Kammerdiener, S. A., Dettinger, M. D., Caprio, J. M., and Peterson, D. H.: Changes in the onset of spring in the western United States, B. Am. Meteorol. Soc., 82, 399-415, 2001.
TCD

7, 2089-2117, 2013

Evidence for spring

mountain snowpack retreat

C. J. Crawford

Title Page

Abstract

Introduction

Conclusions

References

Tables

Figures

14

DI

4

Back

Close

Full Screen / Esc

Printer-friendly Version

Interactive Discussion 
Clark, M. P., Serreze, M. C., and McCabe, G. J.: Historical effects of El Nino and La Nina events on the seasonal evolution of the montane snowpack in the Columbia and Colorado River Basins, Water Resour. Res., 37, 741-757, 2001.

Cline, D. W., Bales, R. C., and Dozier, J.: Estimating the spatial distribution of snow in mountain basins using remote sensing and energy balance modeling, Water. Resour. Res., 34, 1275$1285,1998$.

Comrie, A. C. and Glenn, E. C.: Principal components-based regionalization of precipitation regimes across the southwest United States and northern Mexico, with an application to monsoon precipitation variability, Clim. Res., 10, 201-215, doi:10.3354/cr010201, 1998.

10 Crawford, C. J., Manson, S. M., Bauer, M. E., and Hall, D. K.: Multitemporal snow cover mapping in mountainous terrain for Landsat climate data record development, Remote. Sens. Environ., 135, 224-233, doi:10.1016/j.rse.2013.04.004, 2013.

Derksen, C. and Brown, R.: Spring snow cover extent reductions in the 20082012 period exceeding climate model projections, Geophys. Res. Lett., 39, L19504, doi:10.1029/2012GL053387, 2012.

Dettinger, M. D. and Cayan, D. R.: Large-scale atmospheric forcing of recent trends toward early snowmelt runoff in California, J. Clim., 8, 606-623, doi:10.1175/15200442(1995)008<0606:Isafor>2.0.co;2, 1995.

Duffy, P. B., Arritt, R. W., Coquard, J., Gutowski, W., Han, J., lorio, J., Kim, J., Leung, L. R., Roads, J., and Zeledon, E.: Simulations of present and future climates in the western United States with four nested regional climate models, J. Clim., 19, 873-895, doi:10.1175/jcli3669.1, 2006.

Dyer, J. L. and Mote, T. L.: Trends in snow ablation over North America, Int. J. Climatol., 27, 739-748, doi:10.1002/joc.1426, 2007.

Eischeid, J. K., Baker, C. B., Karl, T. R., and Diaz, H. F.: The quality-control of longterm climatological data using objective data-analysis, J. Appl. Meteorol., 34, 2787-2795, doi:10.1175/1520-0450(1995)034<2787:tqcolt>2.0.co;2, 1995.

Elder, K., Dozier, J., and Michaelsen, J.: Snow accumulation and distrubution in an alpine watershed, Water. Resour. Res., 27, 1541-1552, 1991.

30 Erxleben, J., Elder, K., and Davis, R.: Comparison of spatial interpolation methods for estimating snow distribution in the Colorado Rocky Mountains, Hydrol. Process., 16, 3627-3649, doi:10.1002/hyp.1239, 2002.
TCD

7, 2089-2117, 2013

Evidence for spring

mountain snowpack retreat

C. J. Crawford

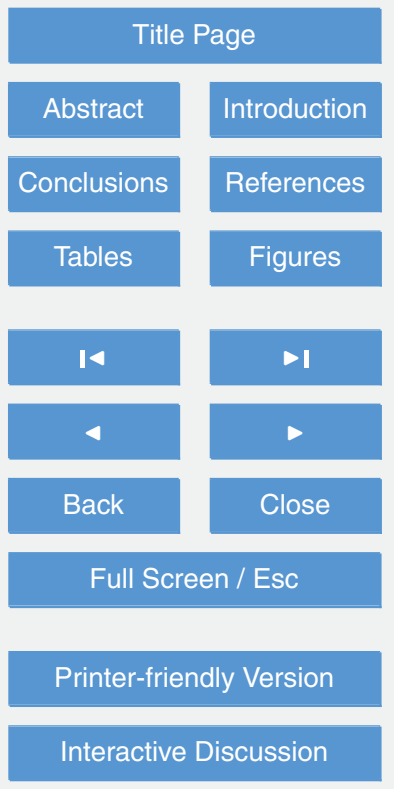


Foster, J. L.: The significance of the date of snow disappearance on the Arctic tundra as a possible indicator of climate change, Arct. Alp. Res., 21, 60-70, doi:10.2307/1551517, 1989.

Frei, A., Robinson, D. A., and Hughes, M. G.: North American snow extent: 1900-1994, Int. J. Climatol., 19, 1517-1534: doi:10.1002/(sici)1097-0088(19991130)19:14<1517:aidjoc437>3.0.co;2-i, 1999.

Groisman, P. and Easterling, D. R.: Variability and trends of total precipitation and snowfall over the United States and Canada, J. Clim., 7, 184-205, 1994.

Groisman, P. Y., Karl, T. R., Knight, R. W., and Stenchikov, G. L.: Changes of snow cover, temperature, and radiative heat-balance over the northern-hemisphere, J. Clim., 7, 16331656, 1994.

Hall, D. K., Foster, J. L., DiGirolamo, N. E., and Riggs, G. A.: Snow cover, snowmelt timing and stream power in the Wind River Range, Wyoming, Geomorphology, 137, 87-93, doi:10.1016/j.geomorph.2010.11.011, 2012.

Hamlet, A. F., Mote, P. W., Clark, M. P., and Lettenmaier, D. P.: Effects of temperature and 15 precipitation variability on snowpack trends in the western United States, J. Clim., 18, 45454561, 2005.

Hurrell, J. W.: Influence of variations in extratropical wintertime teleconnections on Northern Hemisphere temperature, Geophys. Res. Lett., 23, 665-668, 1996.

Jones, P. D. and Hulme, M.: Calculating regional climatic time series for temperature and precipitation: methods and illustrations, Int. J. Climatol., 16, 361-377, 1996.

Knowles, N., Dettinger, M. D., and Cayan, D. R.: Trends in snowfall versus rainfall in the Western United States, J. Clim., 19, 4545-4559, 2006.

Kunkel, K. E., Palecki, M. A., Hubbard, K. G., Robinson, D. A., Redmond, K. T., and Easterling, D. R.: Trend identification in twentieth-century US snowfall: the challenges, J. Atmos. Ocean. Technol., 24, 64-73, doi:10.1175/jtech2017.1, 2007.

Leathers, D. J. and Robinson, D. A.: The association between extremes in North-American snow cover extent and United-States temperature, J. Clim., 6, 1345-1355, 1993.

Li, B. L., Zhu, A. X., Zhou, C. H., Zhang, Y. H., Pei T, and Qin, C. Z.: Automatic mapping of snow cover depletion curves using optical remote sensing data under conditions of frequent cloud cover and temporary snow, Hydrol. Process., 22, 2930-2942, doi:10.1002/hyp.6891, 2008.

Liston, G. E.: Interrelationships among snow distribution, snowmelt, and snow cover depletion: implications for atmospheric, hydrologic, and ecologic modeling, J. Appl. Meteorol., 38, 1474-1487, doi:10.1175/1520-0450(1999)038<1474:iasdsa>2.0.co;2, 1999.
TCD

7, 2089-2117, 2013

Evidence for spring

\section{mountain snowpack} retreat

C. J. Crawford

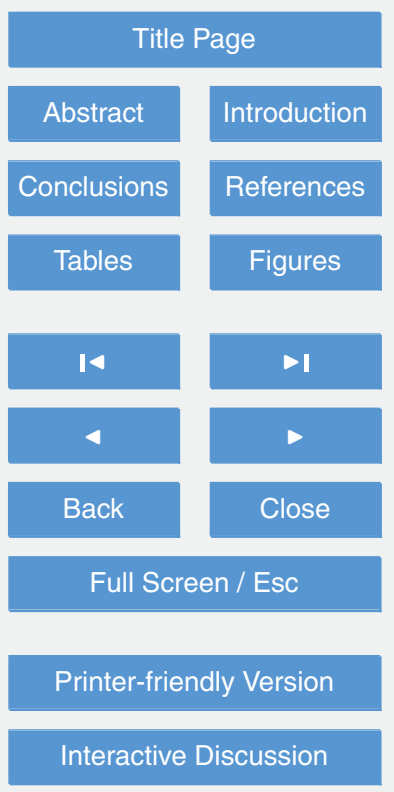


Lundquist, J. D. and Dettinger, M. D.: How snowpack heterogeneity affects diurnal streamflow timing, Water. Resour. Res., 41, W05007, doi:10.1029/2004wr003649, 2005.

Matson, M. and Wiesnet, D. R.: New data-base for climate studies, Nature., 289, 451-456, doi:10.1038/289451a0, 1981.

5 McCabe, G. J. and Clark, M. P.: Trends and variability in snowmelt runoff in the western United States, J. Hydrometeorol., 6, 476-482, 2005.

McCabe, G. J. and Dettinger, M. D.: Primary modes and predictability of year-to-year snowpack variations in the western United States from teleconnections with Pacific Ocean climate, J. Hydrometeorol., 3, 13-25, 2002.

10 McCabe, G. J. and Legates, D. R.: Relationships between, 700 hpa height anomalies and 1 April snowpack accumulations in the western USA, Int. J. Climatol., 15, 517-530, 1995.

Meehl, G. A. and Teng, H. Y.: Case studies for initialized decadal hindcasts and predictions for the Pacific region, Geophys. Res. Lett., 39, L22705, doi:10.1029/2012gl053423, 2012.

Michaelsen, J.: Cross-validation in statistical climate forecast models, J. Appl. Meteorol., 26, 15 1589-1600, 1987.

Mitchell, T. D. and Jones, P. D.: An improved method of constructing a database of monthly climate observations and associated high-resolution grids, Int. J. Climatol., 25, 693-712, doi:10.1002/joc.1181, 2005.

Mitchell, V. L.: The regionalization of climate in the western United States, J. Appl. Meteorol., $20 \quad 15,920-927,1976$.

Molotch, N. P. and Bales, R. C.: Scaling snow observations from the point to the grid element: implications for observation network design, Water. Resour. Res., 41, 16, W11421, doi:10.1029/2005wr004229, 2005.

Mote, P. W., Hamlet, A. F., Clark, M. P., and Lettenmaier, D. P.: Declining mountain snowpack in western north America, B. Am. Meteorol. Soc., 86, 39-49, doi:10.1175/bams-86-1-39, 2005.

Nolin, A. W.: Perspectives on climate change, mountain hydrology, and water resources in the Oregon Cascades, USA, Mt. Res. Dev., 32, S35-S46, doi:10.1659/mrd-journal-d-1100038.s1, 2012.

Nolin, A. W. and Daly, C.: Mapping "at risk" snow in the Pacific Northwest, J. Hydrometeorol., 7, 1164-1171, doi:10.1175/jhm543.1, 2006.

Ostrom, C. W. J.: Time Series Analysis, Regression Techiques, vol. 07-009, Quantitative Applications in the Social Sciences, 2nd Edn., Sage Publications, Newbury Park, 1990.

Evidence for spring

mountain snowpack retreat

C. J. Crawford

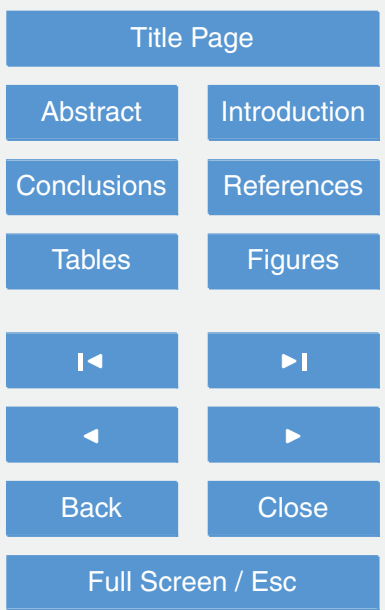

Printer-friendly Version

Interactive Discussion 
Pederson, G. T., Gray, S. T., Woodhouse, C. A., Betancourt, J. L., Fagre, D. B., Littell, J. S., Watson, E., Luckman, B. H., and Graumlich, L. J.: The unusual nature of recent snowpack declines in the North American Cordillera, Science, 333, 332-335, doi:10.1126/science.1201570, 2011.

5 Peterson, T. C., Easterling, D. R., Karl, T. R., Groisman, P., Nicholls, N., Plummer, N., Torok, S., Auer, I., Boehm, R., Gullett, D., Vincent, L., Heino, R., Tuomenvirta, H., Mestre, O., Szentimrey, T., Salinger, J., Forland, E. J., Hanssen-Bauer, I., Alexandersson, H., Jones, P., and Parker, D.: Homogeneity adjustments of in situ atmospheric climate data: a review, Int. J. Climatol., 18, 1493-1517, 1998.

10 Pierce, D. W., Barnett, T. P., Hidalgo, H. G., Das, T., Bonfils, C., Santer, B. D., Bala, G., Dettinger, M. D., Cayan, D. R., Mirin, A., Wood, A. W., Nozawa, T.: Attribution of declining Western US snowpack to human effects, J. Clim., 21, 6425-6444, doi:10.1175/2008jcli2405.1, 2008.

Redmond, K. T. and Koch, R. W.: Surface climate and streamflow variablity in the western 15 United-States and their relationship to large-scale circulation indexes, Water. Resour. Res., 27, 2381-2399, doi:10.1029/91wr00690, 1991.

Robinson, D. A.: Merging operational satellite and historical station snow cover data to monitor climate change, Glob. Planet Change, 90, 235-240, 1991.

Serreze, M. C., Clark, M. P., Armstrong, R. L., McGinnis, D. A., and Pulwarty, R. S.: Characteristics of the western United States snowpack from snowpack telemetry (SNOTEL) data, Water. Resour. Res., 35, 2145-2160, doi:10.1029/1999wr900090, 1999.

Shinker, J. J.: Visualizing spatial heterogeneity of western US climate variability, Earth Interact., 14, 10, doi:10.1175/2010ei323.1, 2010.

Sobolowski, S., Gong, G., and Ting, M.: Northern Hemisphere winter climate variability: response to North American snow cover anomalies and orography, Geophys. Res. Lett., 34, L16825, doi:10.1029/2007gl030573, 2007.

Stewart, I. T., Cayan, D. R., and Dettinger, M. D.: Changes toward earlier streamflow timing across western North America, J. Clim., 18, 1136-1155, doi:10.1175/jcli3321.1, 2005.

Stroeve, J., Holland, M. M., Meier, W., Scambos, T., and Serreze, M.: Arctic sea ice decline: faster than forecast, Geophys. Res. Lett., 34, L09501, doi:10.1029/2007gl029703, 2007.

Sturm, M., Holmgren, J., and Liston, G.,. E.: A seasonal snow cover classificationsystem for local to global applications, J. Clim., 8, 1261-1283, doi:10.1175/15200442(1995)008<1261:assccs>2.0.co;2, 1995.

Evidence for spring

mountain snowpack retreat

C. J. Crawford

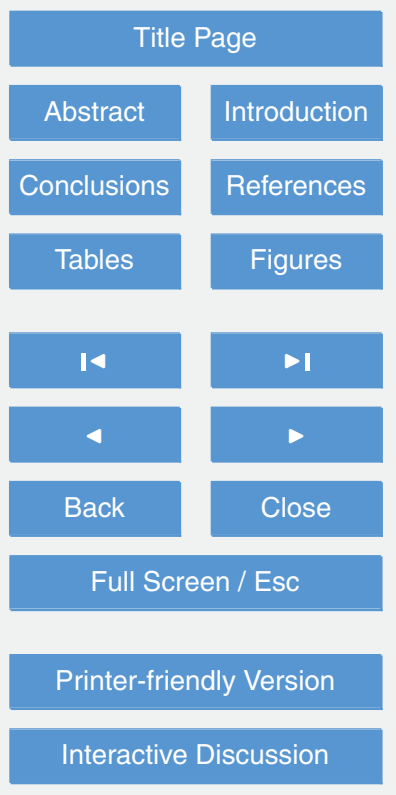

Interactive Discussion

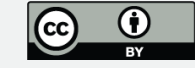


Teng, H. Y., Buja, L. E., and Meehl, G. A.: Twenty-first-century climate change commitment from a multi-model ensemble, Geophys. Res. Lett., 33, L07706, doi:10.1029/2005GL024766, 2006.

Westerling, A. L., Hidalgo, H. G., Cayan, D. R., and Swetnam, T. W.: Warming and 5 earlier spring increase western US forest wildfire activity, Science, 313, 940-943, doi:10.1126/science.1128834, 2006.

Wilks, D. S.: Statistical Methods in the Atmospheric Sciences, Academic Press, Boston, 1995.

Yue, S. and Wang, C. Y.: The Mann-Kendall test modified by effective sample size to detect trend in serially correlated hydrological series, Water. Resour. Manag., 18, 201-218, doi:10.1023/b:warm.0000043140.61082.60, 2004.

Evidence for spring mountain snowpack retreat

C. J. Crawford

Title Page

Abstract

Introduction

Conclusions

References

Tables

Figures

14

$D I$

4

Back

Close

Full Screen / Esc

Printer-friendly Version

Interactive Discussion 
Table 1. Landsat spring SCA-SNOTEL SWE correlation coefficients.

\begin{tabular}{lrrrrrrrrr}
\hline SNOTEL Station & Lat./Long. & $\begin{array}{r}\text { Elevation } \\
(\mathrm{m})\end{array}$ & Time Period & $(n)$ & $1 \mathrm{Apr}$ & $15 \mathrm{Apr}$ & 1 May & 15 May & 1 Jun \\
& & & & & & & & \\
\hline Idaho 524 & $44.02-113.47$ & 2438 & $1981-2009$ & 23 & $0.41^{*}$ & $0.45^{*}$ & $0.62^{*}$ & $0.80^{*}$ & na \\
Idaho 620 & $44.43-113.32$ & 2852 & $1982-2009$ & 21 & 0.11 & 0.11 & 0.26 & $0.52^{*}$ & $0.55^{*}$ \\
Idaho 636 & $44.42-113.40$ & 2268 & $1982-2009$ & 23 & 0.37 & $0.47^{*}$ & $0.65^{*}$ & $0.81^{*}$ & na \\
Idaho 915 & $44.85-113.83$ & 2603 & $1996-2009$ & 13 & 0.14 & 0.14 & 0.32 & $0.74^{*}$ & na \\
Montana 318 & $44.47-112.98$ & 2698 & $1979-2009$ & 23 & 0.35 & $0.61^{*}$ & $0.82^{*}$ & na & na \\
Montana 576 & $45.00-113.45$ & 2469 & $1976-2009$ & 25 & 0.36 & $0.55^{*}$ & $0.76^{*}$ & na & na \\
\hline
\end{tabular}

* Two-tailed significance $(p<0.05)$.

na: no comparison was made because snow had already melted for SNOTEL SWE sites.

Note: the time period for analysis is restricted to years with available Landsat SCA estimates.

Evidence for spring

mountain snowpack retreat

C. J. Crawford

Title Page

Abstract

Introduction

Conclusions

References

Tables

Figures

14

DI

4

Back

Close

Full Screen / Esc

Printer-friendly Version

Interactive Discussion 
Table 2. Spring SCA reconstruction model statistics.

\begin{tabular}{|c|c|c|c|c|c|c|}
\hline \multicolumn{2}{|c|}{$\begin{array}{c}\text { Target } \\
\text { Spring SCA }\end{array}$} & \multicolumn{2}{|c|}{$\begin{array}{c}\text { Predictor } \\
\text { May-June } T_{\text {mean }}^{*}\end{array}$} & \multicolumn{2}{|c|}{$\begin{array}{l}\text { Reconstruction Port. Q } \\
1901-2009 \quad 10.52(p=0.40)\end{array}$} & $\begin{array}{c}\text { DW } \\
2.28 \text { (Accept) }\end{array}$ \\
\hline \multicolumn{7}{|c|}{ PRESS Calibration 1989-2009 } \\
\hline$R^{2}$ & Adj. $R^{2}$ & $F$ stat. & $p$ value & Std. Error & $\mathrm{RE}$ & $\mathrm{RSME}_{\mathrm{v}}$ \\
\hline 0.60 & 0.58 & 28.28 & $<0.001$ & 0.022 & 0.50 & 0.023 \\
\hline
\end{tabular}

${ }^{*}$ CRU TS3.1 regional mean temperature.

Port Q: Portmanteau Q statistic tests whether regression residuals are purely random or white noise.

DW: Durbin-Watson statistic tests for autocorrelation in residuals at lag-1. The null hypothesis states

that there is no autocorrelation. The decision is "Accept" or "Reject".

$\mathrm{RE}$ : Reduction of error statistic measures reconstruction skill in excess of climatology, and is based on the calibration mean. A positive value $>0$ indicates forecast skill.

$\mathrm{RSME}_{\mathrm{v}}$ : Root mean square error - a "leave-one-out" PRESS cross-validation statistic.

\section{$7,2089-2117,2013$}

Evidence for spring mountain snowpack retreat

\section{J. Crawford}

\section{Title Page}

Abstract

Introduction

Conclusions

References

Tables

Figures

14

$>1$

4

Back

Close

Full Screen / Esc

Printer-friendly Version

Interactive Discussion 


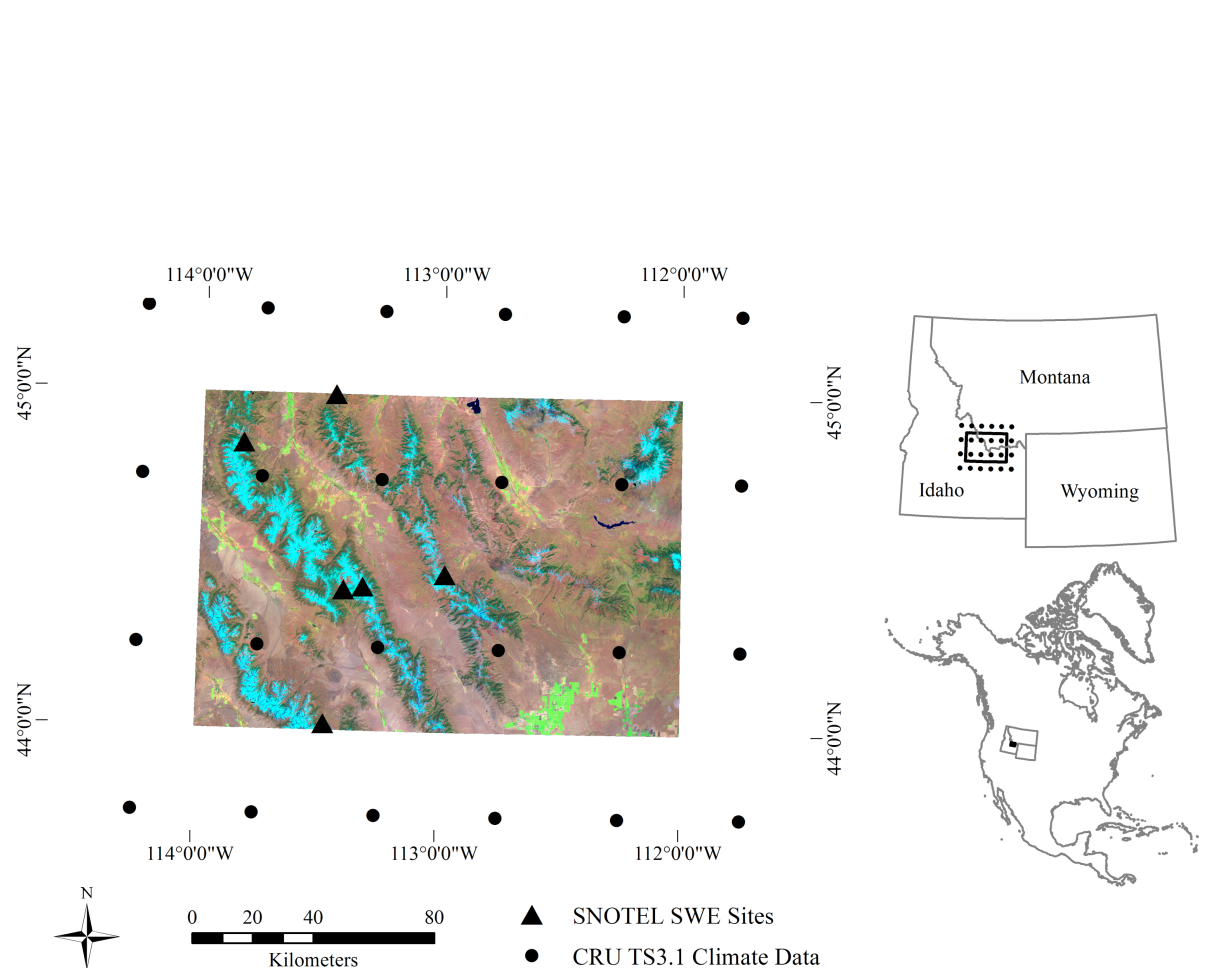

\section{TCD}

7, 2089-2117, 2013

Evidence for spring mountain snowpack retreat

C. J. Crawford

Title Page

Abstract Introduction

Conclusions References

Tables

Figures

14

DI

4

Back

Close

Full Screen / Esc

Printer-friendly Version

Interactive Discussion 

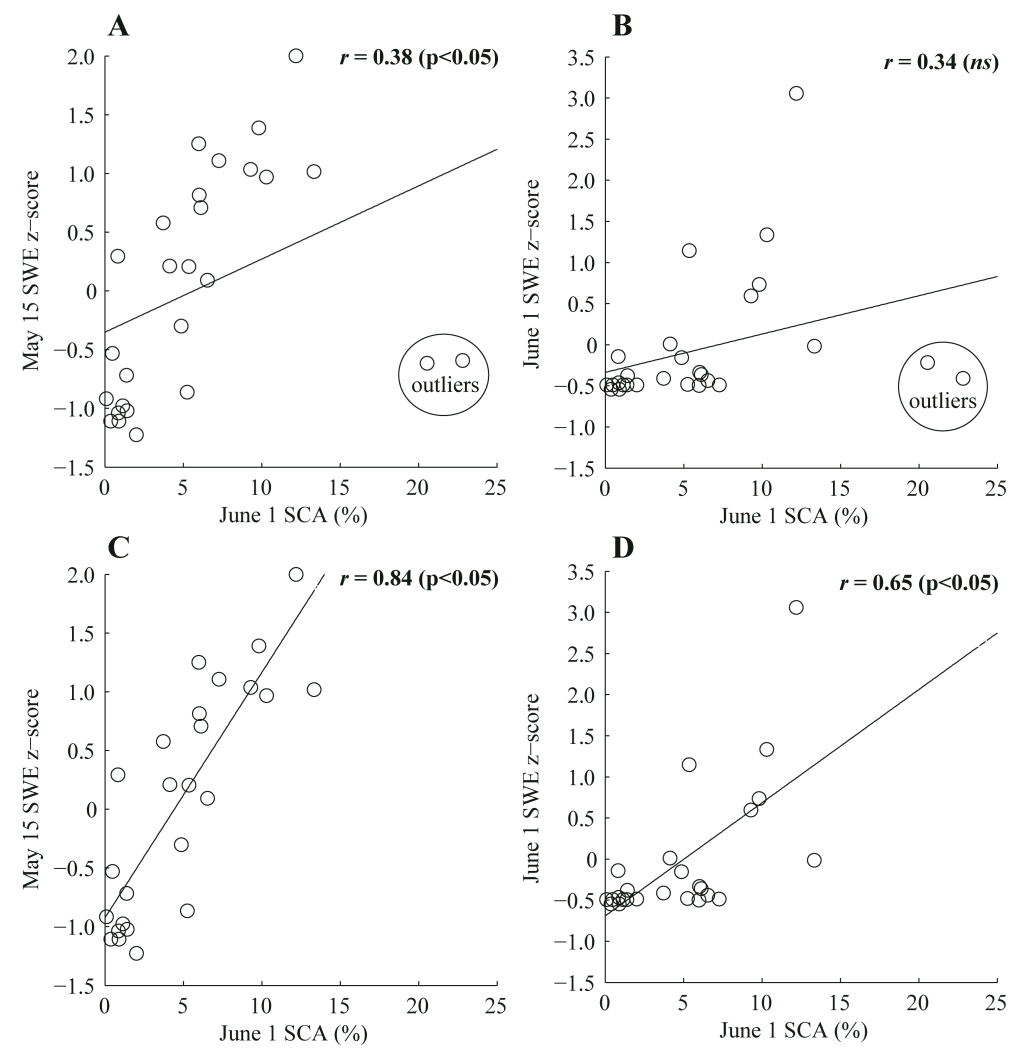

Fig. 2. Scatterplots, linear fits, and correlation coefficients between SCA and SNOTEL SWE for 1976-2009: (A) 1 June SCA and regional 15 May SWE with 1990 and 2002 transient snowfall outliers; (B) 1 June SCA and regional 1 June SWE with 1990 and 2002 transient snowfall outliers; (C) 1 June SCA and regional 15 May SWE without outliers; (D) 1 June SCA and regional 1 June SWE without outliers. Note the change in SWE $z$-scores along the y-axis. NS indicates no statistical significance.

\section{TCD}

$7,2089-2117,2013$

Evidence for spring mountain snowpack retreat

\section{J. Crawford}

\section{Title Page}

Abstract Introduction

Conclusions

References

Tables

Figures

14

$>1$

4

Back

Close

Full Screen / Esc

Printer-friendly Version

Interactive Discussion 
A

Meadow Lake, ID - SNOTEL 620 Beagle Springs, MT - SNOTEL 318 Schwartz Lake, ID SNOTEL 915

TCD
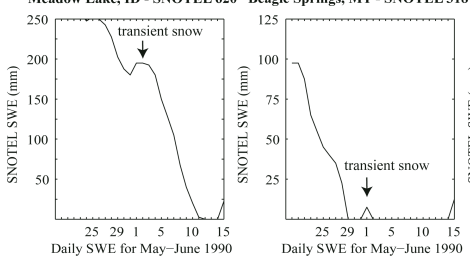

Lemhi Ridge, MT SNOTEL 5

Hilts Creek, ID SNOTEL 524

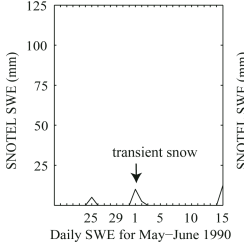

B

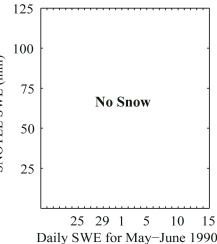

$\begin{array}{rllll}25 & 29 & 5 & 10 & 15\end{array}$
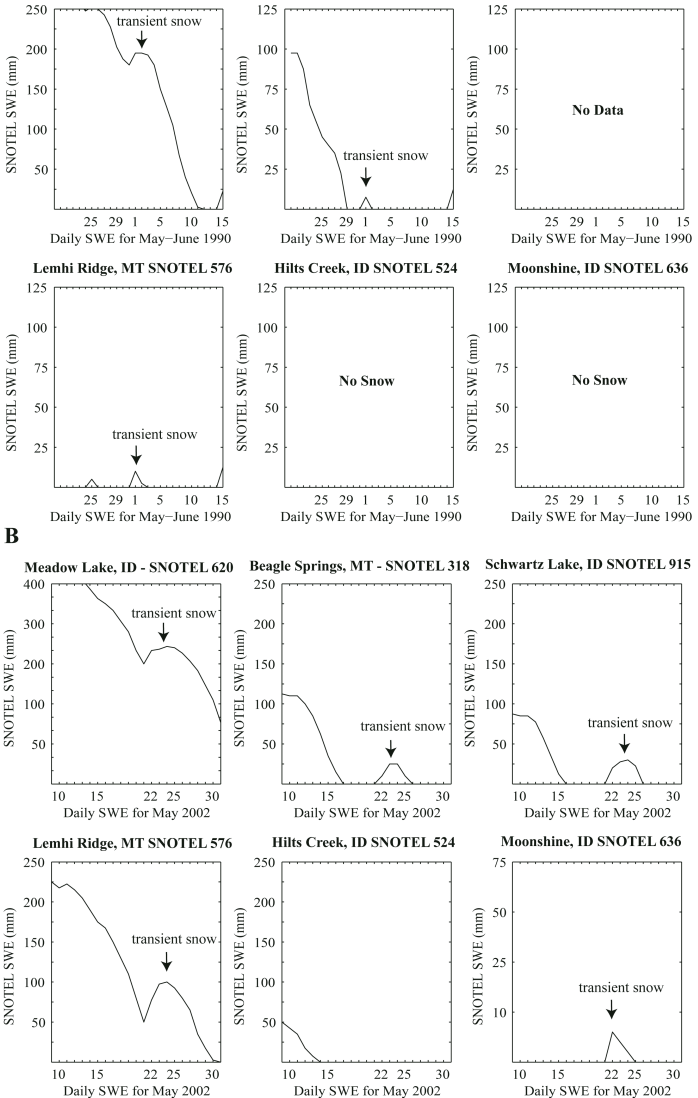

$7,2089-2117,2013$

Evidence for spring mountain snowpack retreat

C. J. Crawford

Title Page

Abstract

Introduction

Conclusions

References

Tables

Figures

14

$>1$

4

Back

Close

Full Screen / Esc

Printer-friendly Version

Interactive Discussion increase in daily SWE highlighted by transient snowfall labels. For 1990, Idaho SNOTEL 915 did not have SWE measurements and had already melted for Idaho SNOTEL 524 and 636. Note the change in SWE $(\mathrm{mm})$ along the y-axis. 

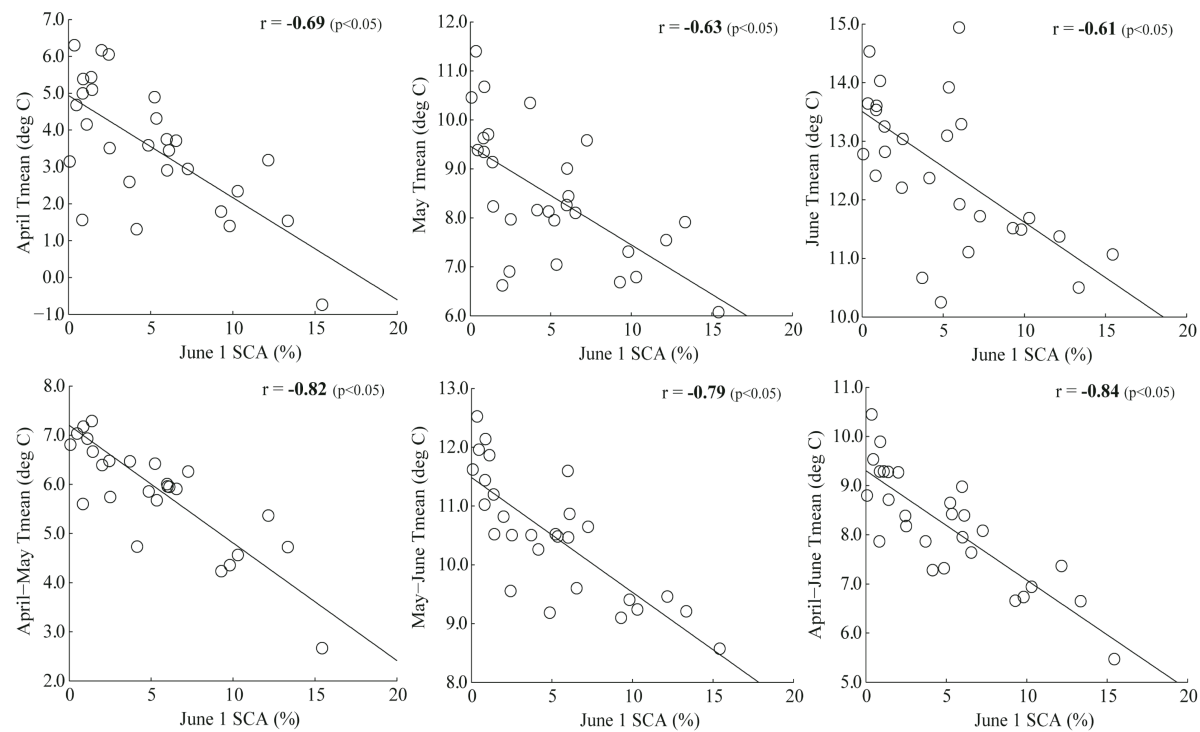

TCD

7, 2089-2117, 2013

Evidence for spring mountain snowpack retreat

C. J. Crawford

Title Page

Fig. 4. Scatterplots, linear fits, and correlation coefficients between 1 June SCA and spring mean temperature (April-June) for the CDR region (1975-2009, $n=28$ ). Note the change in monthly and seasonal temperatures (degrees Celsius) along the y-axis.

14

4

Back

Close

Full Screen / Esc

Printer-friendly Version

Interactive Discussion 


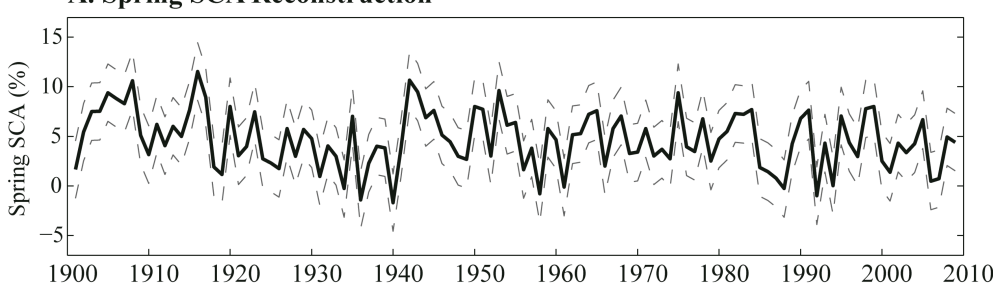

\section{$7,2089-2117,2013$}

Evidence for spring mountain snowpack retreat

B. Spring SCA z-scores

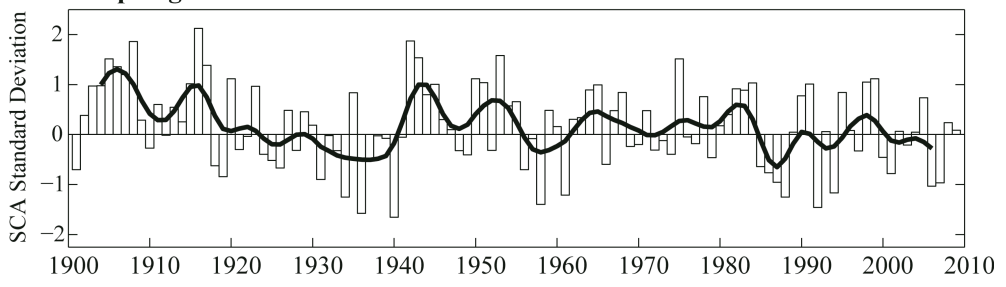

C. $\mathbf{2 0}^{\text {th }}$ - early $21^{\text {st }}$ Century Spring SCA Trend

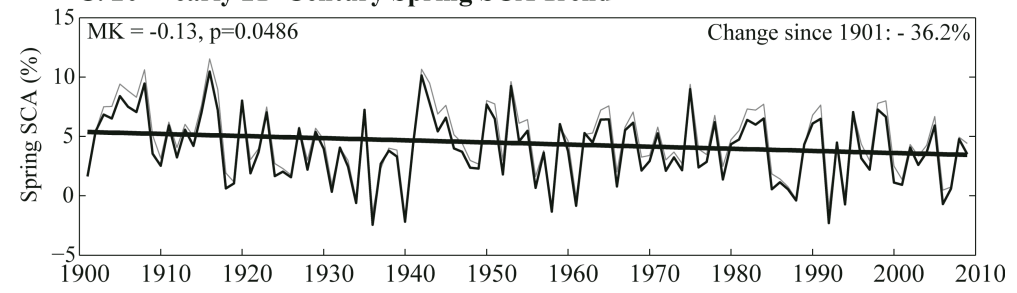

Fig. 5. Spring SCA reconstruction for 1901-2009 using instrumental spring mean temperature records: (A) SCA reconstruction (black line) with $80 \%$ confidence intervals (gray dotted lines); (B) normalized SCA scaled to the calibration mean and standard deviation (1989-2009) with a $50 \%$ frequency response $9 \mathrm{yr}$ binomial filter (black line); (C) centennial spring SCA trend with (black line) and without serial autocorrelation (gray line).

Title Page

Abstract Introduction

Conclusions

References

Tables

Figures

14

$\rightarrow 1$

4

Back

Close

Full Screen / Esc

Printer-friendly Version 
A. Spring SCA (\%) Verification

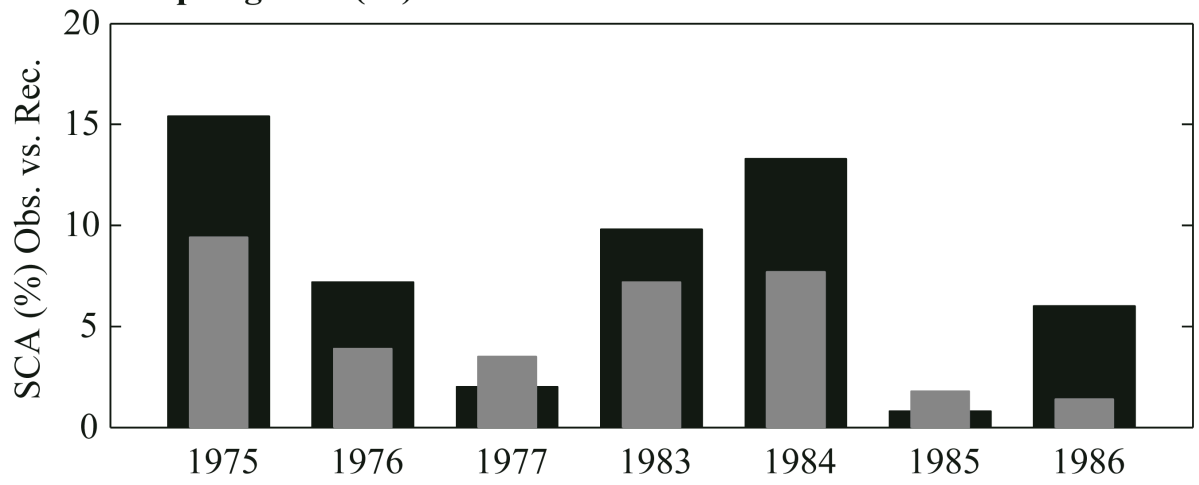

B. Spring SCA (z-score) Verification

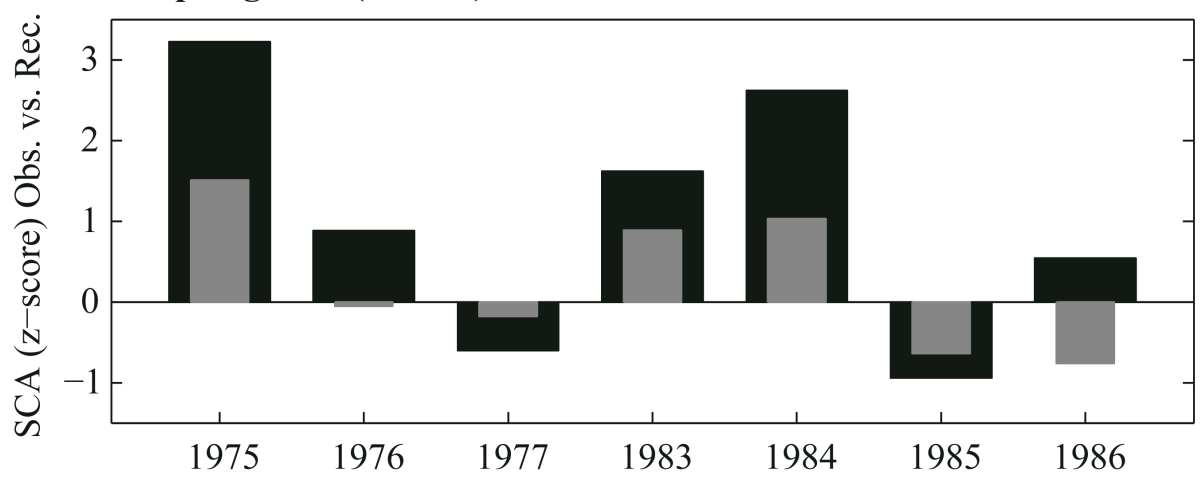

Fig. 6. Spring SCA reconstruction model verification for (A) percent SCA and (B) $z$-score SCA. Observed Landsat SCA (black bars) and reconstructed SCA (grey bars) using instrumental spring mean temperature.

\section{TCD}

\section{7, 2089-2117, 2013}

Evidence for spring mountain snowpack retreat

\section{J. Crawford}

Title Page

Abstract

Introduction

Conclusions

References

Tables

Figures

14

$\rightarrow 1$

4

Back

Close

\section{Full Screen / Esc}

Printer-friendly Version

Interactive Discussion 